$6 R$ (on the application of Pretty) v. DPP [2001] UKHL 61.

7 Pretty v. the United Kingdom [2002] EHRR Application no. 2346/02. 29 April.

8 Guidelines for Crown Prosecutors, Section 10 of the Prosecution of Offences Act 1985 (https://www.opsi.gov.uk/RevisedStatutes/Acts/ ukpga/1985/cukpga_19850023_en_1).

9 Purdy, $R$ (on the application of) $v$. Director of Public Prosecutions \& Ors [2009] EWCA Civ 92.

$10 R$ (on the application of Purdy) (Appellant) v. Director of Public Prosecutions (Respondent) [2009] UKHL 45.

11 Ganzini L, Nelson HD, Schmidt TA, Kraemer DF, Delroit MA, Lee MA Physicians' experiences with the Oregon Death with Dignity Act. N Engl J Med 2000; 342: 557-63.

12 Ganzini L, Goy ER, Dobscha SK. Prevalence of depression and anxiety in patients requesting physicians' aid in dying: cross sectional survey. BMJ 2008; 337: a1682.

13 Gielen J, Van den Branden S, Broeckaert B. Attitudes of European physicians toward euthanasia and physician-assisted suicide: a review of the recent literature. J Palliat Care 2008; 24: 173-84.

14 Ganzini L, Fenn DS, Le MA, Heintz RT, Bloom JD. Attitudes of Oregon psychiatrists toward physician-assisted suicide. Am J Psychiatry 1996; 153: $1469-75$
15 Ganzini L, Leong GB, Fenn DS, Arturo Silva J, Weinstock R. Evaluation of competence to consent to assisted suicide: views of forensic psychiatrists. Am J Psychiatry 2000; 157: 595-600.

16 House of Lords (2005) Assisted Dying for the Terminally III Bill - First Report. HL 86-I, vol. I. TSO (The Stationery Office) (http:// www.publications.parliament.uk/pa/ld200405/Idselect/ldasdy/86/ 8602.htm).

17 Groenewoud J H, van der Heide A, Tholen AJ, Schudel WJ, Hengeveld MW, Onwuteaka-Philipson BD, et al. Psychiatric consultation with regard to requests for euthanasia or physician-assisted suicide. Gen Hosp Psychiatry 2004; 26: 323-30.

18 Ryan CJ, Shaw T. Psychiatric review is mandatory in Australia. BM 2008; 337: a2478.

19 Eagle M. Suicide Act. Hansard Ministerial Statements. House of Commons, 2008 (http://www.publications. parliament.uk/pa/ $\mathrm{cm} 200708 / \mathrm{cmhansrd} / \mathrm{cm} 080917 / \mathrm{wmstext} / 80917 \mathrm{~m} 0001$. htm\#0809173000090).

20 Law Commission. A statement: Amendment of section 2 Suicide Act 1961 September 2008. Pertaining to the report 'Inchoate Liability for Assisting and Encouraging Crime' (2006) Law Com No 300 Cm 6878. Law Commission, 2008 (http://www.lawcom.gov.uk/docs/lc300.pdf).

21 Nugent $\mathrm{H}$. Lord Joffe to resurrect Bill in effort to clarify law. TimesOnline, 30 October 2008 (http://business.timesonline.co.uk/tol/business/ law/article5042490.ece).

\title{
Spirituality and religion in psychiatric practice: why all the fuss? ${ }^{\dagger}$
}

\author{
Michael King, ${ }^{1}$ Gerard Leavey ${ }^{1,2}$
}

The Psychiatrist (2010), 34, 190-193, doi: 10.1192/pb.bp.108.022293

${ }^{1}$ University College London Medical School; ${ }^{2}$ Northern Ireland Association for Mental Health, Belfast

Correspondence to Michael King (m.king@medsch.ucl.ac.uk)
Summary In this article we suggest that controversy over interventions such as prayer in psychiatric practice distracts attention from a serious consideration of the role of spirituality in our society. There is abundant evidence that spiritual belief, experience and practice gives meaning to many people and thus whatever they think of its truth value, psychiatrists cannot ignore it.

Declaration of interest None.

\section{An historical perspective}

In Western societies psychiatric and psychotherapeutic practice emerged out of a secular age that was eager to slough, like so much dead skin, the 'enchantment' of spirituality. $^{2}$ Spirits were less often considered responsible for madness while rational, natural and humane treatments of illness became the accepted healing modalities. Thus it is not surprising that by the late 20th century most UK psychiatrists looked askance at spirituality. ${ }^{3}$ But how did secularism become our modern professional paradigm? One

'See commentary, pp. 193-195, this issue. popular view is that our secular age arose as science progressed and superstitious thinking fell away; however, as Taylor $^{2}$ and others have argued, its origins are more complex.

The current assumption in Western societies that disengaged reason is all we need to understand our world, and flourish in it, seems to have progressed through a number of steps. Briefly, these may be characterised as: (1) ever greater demands by the Christian church from at least the 12th century for lay people to seek moral perfection and not simply participate in religious practice; (2) stripping the natural world of magic and rejection of superstition; (3) the development of Reformation ideas that men and women 
were intrinsically beneficent beings who could achieve ever higher moral excellence; (4) an evolution in Protestant thought that human flourishing, rather than anything higher, was the aim of the religious life; (5) an abandonment of the Christian claim that a moral life was achievable only with the aid of God's grace; and finally (6) a conclusion that a faith emphasising mystical transcendence of self was not only unnecessary but harmful. Scientific progress from the Enlightenment onwards and the accompanying technological advances it ushered in demonstrated the fruits of detached reason. Notwithstanding what some regard as lapses into romanticism or a diversion into postmodern relativism, we duly arrived at the current rationalist view of human perfectibility without reference to God or the transcendent.

\section{Secular humanism}

Most Enlightenment thinkers were Deists in that they conceived of God as architect of the world who worked through universal natural laws but did not intervene directly. Thus the grounds were laid for the final step into secular humanism that leaves God out of the matter altogether. ${ }^{2}$ This, albeit very brief, is the background to the development of psychiatry and psychotherapy. When out of balance, human well-being can be restored by physical treatments or by introspection, either alone or with a therapist, to uncover unhelpful unconscious processes or address cognitive distortions. Rational distancing from thoughts and emotions is used in cognitivebehavioural therapy to move towards fulfilment for the self. In the humanist view, spiritual or religious ideas are extraneous at best or pathological at worst. Thus, liberated from religious enthusiasm or magical flirtation with spirits we are exhorted to confront the apparent indifference and cruelty of Nature by a process of observation and with the help of reason. ${ }^{4}$ The result is the well-lit path from utilitarianism $^{5}$ to modern-day meaning of life. ${ }^{6}$ Through our own effort we can be happy and good.

\section{Transcendence}

Transcendence in its purest sense, whereby men and women reach beyond the limits of their material existence, has largely been lost, not least within the Western religious mainstream. In fact, transcendence beyond the desire for self-gratification is now regarded with suspicion as leading either to the material reductionism exemplified by Marxism and National Socialism or the mass self-annihilation perpetrated by some millennial religious cults. Although the widespread revival of Pentecostal and charismatic movements suggests a human need for experiential or ecstatic religion, psychiatry maintains the detached rationality of modernity, which regards with faint surprise, or even distaste, the undignified suggestion that humanity needs spiritual rescue. ${ }^{2}$ Religious people are casually stereotyped by many social and professional elites as naive, zealous (or at worst both) believers in creationism and/or obsessed with sex.

\section{Meaning}

What does this mean for current psychiatric practice? It strikes most of us, whatever our professional training or personal inclination, that many of the people we see are in what can only be described as a search for meaning. No one in the modern context has expressed this more clearly than Viktor Frankl, a psychiatrist who survived Auschwitz. What meaning remains when all personal resources for human fulfilment are torn out of the centre of one's life? ${ }^{7}$ Before religion became merely another path to self-improvement, a transcendent search of this sort lay at the heart of much spiritual practice. Many of us sense that we work in an abyss of suffering and that no amount of tinkering with our patients' thinking will help them find meaning. At times it strikes us that they would be better served by a priest but what will they get if they seek one? Almost certainly more psychotherapy - many religious leaders seem to have joined us. $^{8}$

\section{Patients and prayer}

Given this historical perspective it is easy to see at first sight why a suggestion that we pray with our patients is regarded as so shocking. It rocks our secular assumptions and seems to welcome irrationality into secular professional practice. But given that elements of Western religion are focused on moral advancement and self-improvement, what is so illogical about prayer (assuming our patients wanted it)? Is it not possible to conceptualise prayer as a complementary or alternative mental process that might alleviate suffering or aid human flourishing? One might expect a detached, reasoned worldview to take a neutral attitude to people praying. If it is simply the superstitious nonsense that many suggest, why worry about prayer - whatever the comfort or ease it provides? Hope is a major element in healing and it might just help our patients to feel that a return to the good life was possible. Some of our psychotherapeutic approaches, for example mindfulness-based cognitive-behavioural therapy, stray very close to spirituality at times. Would it not be useful if we could show that a spiritual approach got people better quicker and back on the road to self-improvement? This idea lies behind the randomised controlled trials of the effectiveness of intercessory prayer ${ }^{9}$ or the evaluation of 12-step programmes for substance misuse. ${ }^{10}$

\section{A moral society}

Despite protests to the contrary, psychotherapy is often a moral enterprise whereby therapists (directly or not, depending on the therapy) dissuade the troubled individual from harmful pursuits and lifestyles. ${ }^{11,12}$ Even psychopharmacology, it has been argued, may enhance morality. ${ }^{13}$ Although the focus in therapy is usually on the individual, the end is to produce a better society. No psychiatrist will work to ensure that their patient is a happy, well-adjusted misogynist, homophobic, abuser. Is this so dissimilar from that of religious injunction? We wonder whether the controversy over praying with patients is simply a slippery red herring that does little to help the chances of rapprochement between the couch and the cloth. We also suspect that few clergy, when confronted by troubled parishioners, will get on bended knee to seek a solely divine solution either., ${ }^{8,14}$ The problem with the 'prayer 
issue' is that it makes it easy for those who see no point in a reasoned discussion of spirituality to caricature it as Biblebanging naivety.

\section{Spirituality and religion}

There seems to be a resurgence of interest in spirituality and religion by psychiatrists: the Royal College of Psychiatrists' Spirituality and Psychiatry Special Interest Group has over 2000 members. We suggest that this reawakening has deeper roots that take us back to that difficult word 'transcendence'. When many people agonise in middle age, 'Is that all there is?', they may have a point. In terms of human flourishing, it probably is. The spiritual quest used to be for something far beyond fulfilment of self. Throughout the ages, almost all religious leaders, prophets, call them what you will, have shown a path towards a transcendent ideal of meaning and union with the absolute. Prayer in this sense becomes an attempt to reach for something beyond oneself. To modern minds this does not even have to be mystical, rather it might be described as living life more intensely. ${ }^{15}$ Central to either approach, however, is a movement away from the tyranny of self. Of course, this search can be mimicked by a material fix of mind-altering drugs ${ }^{16}$ or twisted into religious stereotypes of self-denial and withdrawal from society. ${ }^{15}$ But in its pure form a search for transcendent meaning gazes beyond personal flourishing towards a wider horizon of meaning and purpose. ${ }^{17}$ It is in this sense that spirituality stands out most distinctly from religion, which can be regarded as a more concrete belief in sacred texts and a practice that involves ritual observance. ${ }^{18}$

\section{Spirituality and psychiatry}

So, where does that leave spirituality, religion and psychiatry? Well, it seems reasonable for psychiatry to at least consider spirituality, both clinically and academically. We need not run scared of its mystical appearance. Our contemporary assumptions are certain to be overturned as science, philosophy and the spiritual search move on.

We suggest that a consideration of spirituality is valuable for two reasons. First, there is precious little evidence that human beings can become happy or beneficent through their own reasoned efforts. Although it takes ever new shapes, human misery and corruption is perennial as we saw in the recent world banking crisis. Second, a sense of the spiritual never seems to go away; rather, it adopts new forms and contours. Although some may regard our view of spirituality as a watered down version of religious conviction, in fact it is central to most forms of religious belief. The narratives of religions vary but they all contain faith in the transcendent, something that can never be ultimately defined. Wittgenstein, who was both a religious man and a seeker after what could be said with any 'truth value' about life, put it most pithily:

Christianity is not a doctrine, not I mean a theory about what has happened and what will happen to the human soul, but a description of something that actually takes place in human life. For 'consciousness of sin' is a real event and so are despair and salvation through faith. ${ }^{19}$
Nevertheless, we hesitate to support a third and arguably the most common reason for advocating a consideration of religious belief within psychiatry. We are wary of the large literature that suggests religious belief and practice are associated with better mental health ${ }^{20}$ because the associations are inconsistent and much of the research is flawed methodologically and conceptually. ${ }^{21}$ Even worse, such research easily drifts into the view that (besides the associations of lifestyle and social support) religious belief and spirituality have utility, that in some way they are good for you. ${ }^{22}$ We suggest that this merely returns to the secular theme of self-improvement and thereby grossly undervalues the power of spiritual transcendence to transform broken lives. In Terry Eagleton's words:

'The world . . . belongs to that exceedingly rare class of objects which, in a way that would have delighted the heart of Oscar Wilde, exist entirely for their own sake and for no drearily utilitarian end'.23

\section{Conclusion}

Our review is necessarily brief and in such a short space we cannot do justice to the historical context, the complexity of Reformation thinking on Christian living or the relationship between science and religion. However, we suggest that a debate about spiritual interventions such as prayer is a distraction from a serious consideration of the role of spirituality in people's lives. We suspect that very few psychiatrists will want to pray with their patients. But focusing on prayer in patients who are receptive does not seem very different than teaching them to relax or helping them to address their negative thoughts or underlying cognitive schema. It does not make psychiatrists into priests and, let's face it, secular therapy does not seem to have such a dramatic impact on making people feel better - at least not for more than a while. Although we do not knock feeling better, is it too pompous or idealistic to regard spirituality as something that beckons us (whatever our state or health) beyond ordinary human flourishing into horizons of meaning that might (just) transform our world, let alone our clinical practice? If it were so, psychiatry, as well as the rest of society, might be unwise to ignore it.

\section{About the authors}

Michael King is Professor of Primary Care Psychiatry and Head of the Research Department of Mental Health Sciences, University College London Medical School, and Gerard Leavey is Director of Research, Northern Ireland Association for Mental Health, Belfast, and Honorary Senior Lecturer, University College London Medical School.

\section{References}

1 Koenig HG. Religion and mental health: what should psychiatrists do? Psychiatr Bull 2008; 32: 201-3.

2 Taylor C. A Secular Age. Harvard University Press, 2007.

3 Neeleman J, King MB. Psychiatrists' religious attitudes in relation to their clinical practice: a survey of 231 psychiatrists. Acta Psychiatr Scand 1993; 88: 420-4.

4 Dawkins R. The God Delusion. Bantham Books, 2006.

5 Bentham J, Mill JS. Utilitarianism and Other Essays (ed A Ryan). Penguin Classics, 1987

6 Eagleton T. The Meaning of Life. Oxford University Press, 2007. 
7 Frankl V. Man's Search for Meaning. Rider, 2004.

8 Leavey G, Loewenthal K, King M. Challenges to sanctuary: the clergy as a resource for mental health care in the community. Soc Sci Med 2007; 65: $548-59$

9 Roberts L, Ahmed I, Hall S. Intercessory prayer for the alleviation of ill health. Cochrane Database Syst Rev 2007; 2: CD000368.

10 Humphreys K, Gifford E. Religion, spirituality and the troublesome use of substances. In Rethinking Substance Abuse: What the Science Shows and What We Should Do about It (ed WR Miller, K Carroll): 257-74. Guilford, 2006.

11 Symington N. The Blind Man Sees. Freud's Awakening and Other Essays. Karnac, 2004.

12 Tjeltveit AC. Ethics and Values in Psychotherapy. Routledge, 1999.

13 Spence SA. Can pharmacology help enhance human morality? $\mathrm{Br} J$ Psychiatry 2008; 193: 179-80.

14 Leavey G. UK clergy and people in mental distress: community and patterns of pastoral care. Transcult Psychiatry 2008; 45: 79-104.
15 Armstrong K. The Spiral Staircase. Anchor Books, 2005.

16 Hay D. Exploring Inner Space. Penguin, 1987.

17 Jaspers K. Way to Wisdom. Yale, 1954.

18 King $\mathrm{M}$, Koeing $\mathrm{H}$. Conceptualising spirituality for medical research and health service provision. BMC Health Serv Res 2009; 9: 116.

19 Wittgenstein L. Culture and Value. Blackwell, 1980.

20 Koenig HG. Handbook of Religion and Mental Health. Academic Press, 1998.

21 Sloan RP, Bagiella E, Powell T. Religion, spirituality and medicine. Lancet 1999; 353: 664-7.

22 Schulman JJ, Meador KG. Health Thyself: Spirituality, Medicine and the Distortion of Christianity. Oxford University Press, 2002.

23 Eagleton T. Reason, Faith and Revolution. Reflections on the God Debate: 9 Yale University Press, 2009

\title{
Spirituality, secularity and religion in psychiatric practice
}

\section{Commentary on ... Spirituality and religion in psychiatric practice $^{\dagger}$}

\author{
Christopher C. H. Cook $^{1}$
}

The Psychiatrist (2010), 34, 193-195, doi: 10.1192/pb.bp.109.029108

${ }^{1}$ Durham University, UK

Correspondence to Christopher C. H. Cook (c.c.h.cook@durham.ac.uk)
Summary Spirituality and religion, in our secular age, are subject to what Charles Taylor calls 'closed world structures' which make disbelief in transcendence appear incontrovertible when in fact, rationally speaking, it is not. It is arguably an effect of these closed world structures on psychiatric practice that excludes from the clinical consultation spiritual matters which patients themselves wish to discuss with their psychiatrist. In fact, the evidence base suggests that spirituality and religion should be routinely assessed in psychiatric practice and that the possible beneficial influence on outcome of spiritual practices and faith communities should be considered when formulating treatment plans.

Declaration of interest None.
King \& Leavey ${ }^{1}$ offer some helpful reflections on Charles Taylor's A Secular Age, ${ }^{2}$ as a basis for better understanding the relationship between spirituality and psychiatry. In $A$ Secular Age, Taylor, a leading philosopher and Templeton Prize winner, charts the currents by which we may understand secularity to have become what it is in Western society today. However, King \& Leavey interpret his sophisticated, lengthy and nuanced account in such a way as to make it appear that transcendence has been lost forever and that spirituality is left with a limited sphere of legitimacy, confined largely to finding meaning in life. Their

†See special article, pp. 190-193, this issue. conclusions about its significance for psychiatric practice are accordingly limited and ambiguous.

\section{Secularity}

Taylor clarifies early in his book the different possible meanings of the word 'secularity'. He focuses his attention on one of these, the way in which religious belief has become for us just one option among many, a state of affairs almost completely unknown to pre-modern societies. Many people assume that this is simply due to the rise of science in such a way as to leave superstitious and religious thought without plausible basis, thus allowing 'secular' ways of thinking to flourish in their place. Taylor argues that this 